\title{
Effect of Lychee Peel Aqueous Extract on Kadaknath and Cobb Chicken Meat Patties during Refrigerated Storage $\left(4 \pm 2^{\circ} \mathrm{C}\right)$
}

\author{
Pal Ankita ${ }^{1 *}$, Malik Ashok ${ }^{1}$, Kumar Surender ${ }^{1}$, Jangir Apeksha ${ }^{2}$ and Chopra Deeapk ${ }^{3}$ \\ ${ }^{1}$ Department of Livestock Products Technology, College of Veterinary Sciences, Lala Lajpat Rai University of Veterinary $\mathcal{E}$ \\ Animal Sciences, Hisar, Haryana, INDIA \\ ${ }^{2}$ Department of Livestock Products Technology, College of Veterinary Sciences, Guru Angad Dev Veterinary and Animal Sciences \\ University, Ludhiana, Punjab, INDIA \\ ${ }^{3}$ Department of Livestock Production Management, College of Veterinary Sciences, Lala Lajpat Rai University of Veterinary $\mathcal{E}$ \\ Animal Sciences, Hisar, Haryana, INDIA \\ *Corresponding author: A Pal; E-mail: ankitapal24@gmail.com
}

Received: 01 Feb., 2021

Revised: 21 June, 2021

Accepted: 17 July, 2021

\begin{abstract}
This study was conducted to develop cobb and kadaknath chicken meat patties separately by incorporating Lychee fruit peel extract (LFPE) and BHT (butylated hydroxyl toluine) individually as antioxidant and to evaluate the effect on storage quality of developed products. Control patties were developed without adding any antioxidants. Sensory scores of kadaknath and cobb patties incorporated with BHT and LFPE were equivalent to respective controls on fresh basis. The sensory color scores of kadakanath patties were significantly lower than cobb patties however flavor, texture, tenderness, juiciness and overall acceptability scores were statistically comparable for both types of patties on fresh basis. Sensory scores decreased and microbial counts increased significantly during refrigerated storage for all the treatments but scores for treated patties were significantly higher than respective controls. At the end of storage TBA and microbial counts for LFPE treated patties were significantly lower than their respective control and BHT treatments. It is concluded that incorporation of $15 \mathrm{ml}$ lychee peel aqueous extract per $100 \mathrm{~g}$ of kadaknath and cobb chicken meat resulted in the production of healthier patties. Lychee extract provides better protection against oxidative rancidity and microbial proliferation during refrigerated storage and can well used as a replacement of synthetic antioxidants like BHT.
\end{abstract}

\section{HIGHLIGHTS}

(0 The sensory color scores of kadakanath patties were significantly lower than cobb patties.

0 Lychee extract provides better protection against oxidative rancidity and microbial proliferation during refrigerated storage of chicken patties.

Keywords: Kadaknath, cobb, chicken, lychee peel extract, meat patties, storage

The contribution of poultry meat in total meat production in India is 4.06 million tons which accounts for $50 \%$ of India's total meat production. Meat production has increased by $6.0 \%$ as compared to last year with poultry meat production increasing at $7.8 \%$ (BAHFS, 2019). Cobb-400 is a commercial poultry breed for efficient meat production. It has the lowest cost of live weight produced and shows a superior performance on low cost feed rations. In India, the native breeds also play a major role in the total poultry production. Kadaknath chicken meat is famous for its taste and claimed aphrodisiac and medicinal properties. The blood, meat and body of the birds are black, as compared to other poultry breeds kadaknath meat is

How to cite this article: Ankita, P., Ashok, M., Surender, K., Apeksha J. and Deeapk, C. (2021). Effect of Lychee Peel Aqueous Extract on Kadaknath and Cobb Chicken Meat Patties during Refrigerated Storage $\left(4 \pm 2^{\circ}\right.$ C). J. Anim. Res., 11(04): 587-597.

Source of Support: None; Conflict of Interest: None 
high in protein and also, contains essential amino acids and vitamins B-1, B-2, B-6, B-12, C and E (Chand et al., 2011). Kadaknath is an important indigenous breed of poultry inhabiting vast areas of western Madhya Pradesh mainly, the Jhabua and Dhar districts and adjoining areas of Gujarat and Rajasthan. This breed is poor in egg production however their black flesh is very delicious and popular. Kadaknath chicken meat is famous for its taste and claimed aphrodisiac and medicinal properties. Kadaknath chicken meat is used by tribals for effectiveness in treating sterility, menoxenic conditions (abnormal menstruation), habitual abortion (Azad, 2018). Kadaknath are well known for their tropical adaptability and disease resistance (Verma, 2020).

In meat products, antioxidants are extensively employed to prevent oxidation and for conserving the quality attributes. The synthetic antioxidants used in meat products are nitrites and nitrates, ascorbic acid, butylated hydroxyl toluene (BHT), butylated hydroxyl anisole (BHA), may involved in etiology of stomach, bowel and food allergy (Pereira et al., 2015). Besides, BHT and BHA can cause mutations in the DNA, triggering the onset of neoplasia (Aun et al., 2011). Considering these health issues the meat industry now chooses natural antioxidants for various products to address health concerns, delay oxidative degradation of lipids and maintain quality and nutritional value of meat and meat products (Kumar et al., 2015).

Lychee (Litchi chinensis Sonn.), a popular fruit cultivated commercially in tropical and subtropical regions, are favored by consumers for their fascinating taste and attractive red pericarps (Pareek, 2016). This fruit has been evaluated for high nutritional value by many types of researches. Researchers have verified a long series of beneficial health compounds including antioxidant, cancer preventive, antimicrobial, anti-inflammatory activities etc. So in 2012, Lychee chinensis was inserted in the list of functional foods (U.S.D.A, 2012). Usually, the pericarp of the lychee is wasted or thrown away. Lychee peel (LP) is reported to contain a large number and amount of phenolics which possess antioxidant, anticancer and immune modulatory activities. So, it is considered to be a good source of functional foods (Li et al., 2012; Lin et $a l ., 2015)$. So, considering above facts lychee peel aqueous extract was incorporated to develop cobb and kadaknath meat patties.

\section{MATERIALS AND METHODS}

\section{Procurement and processing of raw materials}

Healthy cobb and kadaknath chicken reared under similar feeding and management conditions were procured from nearby market and slaughtered and dressed as per the standard procedure. The dressed carcasses were washed thoroughly and deboned manually after trimming of visible fat and connective tissue. Deboned meat was packed in colorless low density polyethylene (LDPE) bags at $-18 \pm 2{ }^{\circ} \mathrm{C}$. The frozen chunks were taken out and thawed overnight at $4 \pm 2^{\circ} \mathrm{C}$ and used for preparation of chicken meat patties.

Lychee peels after purchase from the local market were washed gently with clean water. Peels were then squeezed through a muslin cloth and dried in a hot air drier at 50$55^{\circ} \mathrm{C}$ for 2-3 days. Dried peels were ground to a fine powder in a grinder, packed in a polythene bag and stored at $18 \pm 2^{\circ} \mathrm{C}$ for further use. For preparing lychee peel aqueous extract, $10 \mathrm{~g}$ of dried powder was mixed in 100 $\mathrm{ml}$ of distilled water. The mixtures were incubated for overnight at room temperature and filtered through filter paper and the filtrate was used to incorporate in chicken meat patties.

\section{Preparation of chicken meat patties}

Both kinds of deboned frozen meat were cut into small pieces separately and minced in an electrical mincer. For control meat patties of both types, $100 \mathrm{~g}$ of minced meat of both types was taken individually in which sodium chloride $(1.9 \mathrm{~g})$, sodium tripolyphosphate $(0.4 \mathrm{~g})$, sodium nitrite $(150 \mathrm{ppm})$, spice mix $(2 \mathrm{~g})$, condiments $(3 \mathrm{~g})$ (ginger and garlic in the ratio of 1:1), bread crumbs (2 g), water $(10 \mathrm{~g})$ egg liquid $(5 \mathrm{~g})$ and fat $(15 \mathrm{~g})$ were added and blended with the minced meat in a mixer for 4 to 5 minutes and stable emulsions were prepared. For treated meat patties $15 \mathrm{ml}$ of lychee powder aqueous extract were added separately. Approximately $60 \mathrm{~g}$ of meat emulsion was hand moulded into a patty shape with the help of a petri dish. Patties were prepared by baking in a preheated oven at a temperature of $160^{\circ} \mathrm{C}$ for 35 minutes ( 20 minutes first side and 15 minutes second side). 


\section{Analysis}

\section{Sensory Quality}

A semi trained panel comprising of faculty and research fellows analyzed the chicken patties for the sensory quality in terms of color and appearance, flavor, texture, tenderness, juiciness and overall acceptability using 8 point descriptive scale (Keeton, 1983), where 8 indicating excellent and 1 showing extremely poor. The warmed test samples were served to the panelists after assigning the suitable codes. Water was rendered for rinsing the mouth between different samples.

\section{pH and Thiobarbituric acid (TBA) value}

The $\mathrm{pH}$ of chicken patties was determined with $\mathrm{pH}$ meter (Cyber Scan pH 510, Eutech Instruments; Thermo Fisher Scientific, Navi Mumbai) equipped with a combined glass electrode as per method of Trout et al. (1992). TBA value of raw emulsion and cooked patties was determined according to the method of Witte et al. (1970).

\section{Microbiological evaluation}

Total plate counts (TPC) and psychrotrophic counts of the samples were enumerated following the methods as described by FSSAI (2011).

\section{RESULTS AND DISCUSSION}

\section{Sensory Quality}

\section{Color scores}

No significant difference was noticed in color scores of control and treated cobb meat patties on 0 day of storage (Table 1). The findings were in favour with the findings of Verma et al. (2020) who reported the score of 7.24 for control and 7.15 for treatment. Das et al. (2016) also found score of 7.23 for control 7.12 for treatment in meat products with LFPE and LP incorporation respectively. For cobb meat patties scores for color decreased with an increase in storage period irrespective of the treatments. A significant decline in color scores in comparison to their fresh counterparts was noticed on the $8^{\text {th }}$ day in $\mathrm{C}_{\mathrm{C}}$ (cobb control), $\mathrm{C}_{\mathrm{BHT}}$ (cobb BHT), $\mathrm{C}_{\mathrm{LFPE}}$ (cobb LFPE) treatments. On the $8^{\text {th }}$ day and onwards, treatments $\mathrm{C}_{\mathrm{LFPE}}$ had significantly higher color scores in comparison to $\mathrm{C}_{\mathrm{c}}$ and $\mathrm{C}_{\mathrm{BHT}}$. Pigment and lipid oxidation might have contributed to a decrease in color scores of chicken patties during refrigerated storage (Bhat et al., 2011). Color scores of $\mathrm{C}_{\mathrm{LFPE}}$ patties were near to 7.0 meaning very good acceptability. $\mathrm{C}_{\mathrm{BHT}}$ treatment had color scores between 5.0 and 6.0 meaning slight to moderate acceptability on the $16^{\text {th }}$ day of storage BHT, while $\mathrm{C}_{\mathrm{C}}$ patties had color scores of 5.0 meaning slight acceptability.

Table 1: Effect of type of meat and incorporation of lychee fruit peel extract on color scores of chicken meat patties packaged in aerobic conditions and stored at $4 \pm 2^{\circ} \mathrm{C}(\mathrm{Mean} \pm \mathrm{SD})(\mathrm{n}=12)$

\begin{tabular}{|c|c|c|c|c|c|}
\hline Treatments & $\mathbf{0}$ & 4 & 8 & 12 & 16 \\
\hline $\mathrm{C}_{\mathrm{C}}$ & $7.79^{\mathrm{aA}} \pm 0.25$ & $7.58^{\mathrm{aA}} \pm 0.51$ & $6.95^{\mathrm{bB}} \pm 0.62$ & $6.41^{\mathrm{cdC}_{ \pm}} \pm .41$ & $5.166^{\mathrm{dD}_{ \pm 0}}$ \\
\hline $\mathrm{C}_{\mathrm{BHT}}$ & $7.83^{\mathrm{aA}} \pm 0.24$ & $7.62^{\mathrm{aA}} \pm 0.37$ & $7.04^{\mathrm{bB}} \pm 0.72$ & $6.95^{\mathrm{bB}} \pm 0.49$ & $5.62^{\mathrm{cC}} \pm 0.48$ \\
\hline $\mathrm{C}_{\mathrm{LFPE}}$ & $7.79^{\mathrm{aA}} \pm .33$ & $7.70^{\mathrm{aAB}_{ \pm}} .39$ & $7.58^{\mathrm{aAB}_{ \pm} 0.35}$ & $7.41^{\mathrm{aB}} \pm 0.28$ & $6.75^{\mathrm{aC}_{ \pm}} .33$ \\
\hline $\mathrm{K}_{\mathrm{C}}$ & $6.83^{\mathrm{bA}} \pm 0.49$ & $6.66^{\mathrm{bAB}} \pm 0.38$ & $6.33^{\mathrm{cBC}} \pm 0.32$ & $6.08^{\mathrm{dCD}} \pm 0.41$ & $5.79^{\mathrm{cD}} \pm 0.54$ \\
\hline $\mathrm{K}_{\mathrm{BHT}}$ & $6.87^{\mathrm{bA}} \pm 0.48$ & $6.75^{\mathrm{bAB}} \pm 0.33$ & $6.5^{\mathrm{cBC}_{ \pm}} \pm .36$ & $6.33^{\mathrm{cdC}} \pm 0.38$ & $6.16^{\mathrm{bC}} \pm 0.32$ \\
\hline $\mathrm{K}_{\mathrm{LFPE}}$ & $7.08^{\mathrm{bA}} \pm 0.56$ & $6.87^{\mathrm{bAB}} \pm 0.60$ & $6.66^{\mathrm{bcBC}} \pm 0.32$ & $6.5^{\mathrm{cC}} \pm 0.47$ & $6.41^{\mathrm{bC}_{ \pm 0}} .28$ \\
\hline
\end{tabular}

Means with different small letter superscripts in a column and capital letter superscript in a row differ significantly $(\mathrm{P} \leq 0.05)$.

$\mathrm{C}_{\mathrm{C}}$ - Cobb control meat patties, $\mathrm{C}_{\mathrm{BHT}}-$ Cobb chicken patties with 100 ppm BHT, $\mathrm{C}_{\mathrm{LFPE}}$ - Cobb chicken patties with 15 ml lychee fruit peel extract $\mathrm{K}_{\mathrm{C}}$ - Kadaknath chicken control patties, $\mathrm{K}_{\mathrm{BHT}}-$ Kadaknath chicken patties with 100 ppm BHT, $\mathrm{K}_{\mathrm{LFPE}}$ - Kadaknath chicken patties with $15 \mathrm{ml}$ lychee fruit peel extract. 
On 0 day of storage, kadaknath meat patties had a significantly lower score than that of cobb meat patties (Table 1). Which might be due to its blackish color which is less likable than cobb patties. A significant decline in color scores in comparison to their fresh counterparts was noticed on the $8^{\text {th }}$ day in $\mathrm{K}_{\mathrm{C}}$ (kadaknath control), $\mathrm{K}_{\mathrm{BHT}}$ (kadaknath BHT), $\mathrm{K}_{\text {LFPE }}$ (kadaknath LFPE) treatments. On the $8^{\text {th }}$ day of storage, treatments $\mathrm{K}_{\mathrm{LFPE}}$ had significantly higher color scores in comparison to $\mathrm{K}_{\mathrm{C}}$ and $\mathrm{K}_{\mathrm{BH}}$. On the $16^{\text {th }}$ day extract treated and BHT kadaknath patties had higher color scores in comparison to control. Color scores of extract and BHT patties were around 6.0 meaning moderate acceptability on the $16^{\text {th }}$ day of storage, while control kadaknath patties had color scores of 5.0 meaning slight acceptability. The decrease in the color score with an increase in the storage time of kadaknath meat products was also reported by Badole (2019). These findings were also in conformance with Kandeepan (2010) and Nayak (2014).

\section{Flavor scores}

Flavor scores declined significantly in all the treatments with the advancement of storage days during refrigerated storage (Table 2). Devatkal et al. (2003) reported that deterioration of flavor during storage might be due to microbial growth and oxidative rancidity. But the decline was more in control treatment as compared to treatments. The treated patties were able to maintain their flavor score in a better way in comparison to control. Kadaknath has higher flavor scores compared to that of broilers as reported by Mir et al. (2017). The reason for flavor difference might be due to variations in the content of Inosine-50-monophosphate (IMP).

From the $4^{\text {th }}$ day onwards, both controls had significantly lower flavor scores in comparison to LFPE treatments on each day of storage of both patties. On the $12^{\text {th }}$ and $16^{\text {th }}$ day of refrigerated storage, extract treated kadaknath and cobb patties had significantly higher flavor scores in comparison to respective control. Both types of extract treated patties had significantly higher flavor scores in comparison to BHT on the $16^{\text {th }}$ day of storage. BHT patties also had significantly better flavor scores than control on the $12^{\text {th }}$ and $16^{\text {th }}$ day of storage. On the $16^{\text {th }}$ day of storage, both types of extract treated patties had flavor scores more than 6.0 meaning moderate desirability.

The highest flavor scores of 6.33 were noticed in LFPE treated kadaknath patties. Both types of BHT patties flavor scores were between 5.0 and 6.0 indicating slight to moderate desirability whereas both control patties had flavor scores around 5.0 meaning slight desirability. Phenolic and bioactive compounds present in LFPE slowed down the development of oxidative rancidity and deteriorative changes. Similar resulted were also reported by Verma et al. (2020) and Das et al. (2016) as suggested in meat products with LFPE and LP incorporation respectively.

Table 2: Effect of type of meat and incorporation of lychee fruit peel extract on flavor scores of chicken meat patties packaged in aerobic conditions and stored at $4 \pm 2^{\circ} \mathrm{C}(\mathrm{Mean} \pm \mathrm{SD})(\mathrm{n}=12)$

\begin{tabular}{|c|c|c|c|c|c|}
\hline Storage days & $\mathbf{0}$ & 4 & 8 & 12 & 16 \\
\hline $\mathrm{C}_{\mathrm{C}}$ & $7.87^{\mathrm{aA}} \pm 0.22$ & $7.54^{\mathrm{aA}} \pm 0.45$ & $7.04^{\mathrm{cB}} \pm 0.25$ & $5.54^{\mathrm{cC}} \pm 0.62$ & $4.83^{\mathrm{dD}} \pm 0.65$ \\
\hline $\mathrm{C}_{\text {BHT }}$ & $7.87^{\mathrm{a} A_{ \pm}} \pm 0.31$ & $7.50^{\mathrm{aB}} \pm 0.42$ & $7.25^{\mathrm{bcB}} \pm 0.26$ & $6.16^{\mathrm{bC}_{ \pm}}+38$ & $5.37^{\mathrm{bcD}} \pm 0.64$ \\
\hline $\mathrm{C}_{\text {LFPE }}$ & $7.83^{\mathrm{aA}} \pm 0.24$ & $7.62^{\mathrm{aA}} \pm 0.43$ & $7.66^{\mathrm{aA}} \pm 0.32$ & $6.75^{\mathrm{aB}_{ \pm}} 0.58$ & $6.29^{\mathrm{aC}_{ \pm}}+5.54$ \\
\hline $\mathrm{K}_{\mathrm{C}}$ & $7.91^{\mathrm{aA}} \pm 0.19$ & $7.62^{\mathrm{aA}} \pm 0.37$ & $7.12^{\mathrm{bcB}} \pm 0.22$ & $5.62^{\mathrm{CC}_{ \pm}} \pm 0.74$ & $4.91^{\mathrm{cdD}_{ \pm}} \pm 0.73$ \\
\hline $\mathrm{K}_{\mathrm{BHT}}$ & $7.95^{\mathrm{aA}} \pm 0.14$ & $7.58^{\mathrm{aB}} \pm 0.41$ & $7.33^{\mathrm{bB}} \pm 0.24$ & $6.25^{\mathrm{bC}} \pm 0.45$ & $5.45^{\mathrm{bD}} \pm 0.6$ \\
\hline $\mathrm{K}_{\text {LFPE }}$ & $7.87^{\mathrm{aA}} \pm 0.22$ & $7.70^{\mathrm{aA}} \pm 0.33$ & $7.75^{\mathrm{aA}} \pm 0.26$ & $6.83^{\mathrm{aB}} \pm 0.53$ & $6.37^{\mathrm{aC}_{ \pm}} \pm 0.43$ \\
\hline
\end{tabular}

Means with different small letter superscripts in a column and capital letter superscript in a row differ significantly $(\mathrm{P} \leq 0.05)$.

$\mathrm{C}_{\mathrm{C}}$ - Cobb control meat patties, $\mathrm{C}_{\mathrm{BHT}}{ }^{-}$Cobb chicken patties with $100 \mathrm{ppm}$ BHT, $\mathrm{C}_{\mathrm{LFPE}}{ }^{-}$Cobb chicken patties with 15 ml lychee fruit peel extract $\mathrm{K}_{\mathrm{C}}$ - Kadaknath chicken control patties, $\mathrm{K}_{\mathrm{BHT}}$ - Kadaknath chicken patties with $100 \mathrm{ppm}$ BHT, $\mathrm{K}_{\mathrm{LFPE}}$ - Kadaknath chicken patties with $15 \mathrm{ml}$ lychee fruit peel extract. 


\section{Texture scores, Tenderness and Juiciness score}

A significant decline was noticed in texture, tenderness and juiciness scores of control and treated patties with an increase in storage period (Table 3, 4 and 5). However, the decline was more in control patties.

However, the rate of decline for these sensory attributes was less in treated patties resulting in significantly better texture, tenderness, and juiciness scores in comparison to control at the end of storage. On the $12^{\text {th }}$ day of storage, both cobb and kadaknath patties treated with extract had higher texture, tenderness, and juiciness scores in comparison to respective control.

The similar results were reported by Das et al. (2016) in his study on the incorporation of lychee pericarp extract in sheep meat nuggets. Verma et al. (2020) also reported a higher juiciness score of meat with treatment lychee pericarp incorporation. The decreasing trend in texture score during storage under refrigeration in meat products were also reported in chicken patties and in vacuum packaged restructured chicken steak by (Kala et al., 2007; Sudheer et al., 2011). The decreasing value of juiciness with the advancement of storage in chicken meat products was also reported by Uikey et al. (2018).

\section{Overall acceptability scores}

OAA scores decreased significantly in all the treatments with an increase in the storage period (Table 6). However, the decrease was less in both types of extract treated

Table 3: Effect of type of meat and incorporation of lychee fruit peel extract on texture scores of chicken meat patties packaged in aerobic conditions and stored at $4 \pm 2^{\circ} \mathrm{C}(\mathrm{Mean} \pm \mathrm{SD})(\mathrm{n}=12)$

\begin{tabular}{|c|c|c|c|c|c|}
\hline Treat & $\mathbf{0}$ & 4 & 8 & 12 & 16 \\
\hline $\mathrm{C}_{\mathrm{C}}$ & $7.79^{\mathrm{aA}} \pm 0.25$ & $7.41^{\mathrm{aB}} \pm 0.46$ & $7.16^{\mathrm{aB}} \pm 0.32$ & $6.04^{\mathrm{dC}} \pm 0.49$ & $4.91^{\mathrm{cD}} \pm 0.46$ \\
\hline $\mathrm{C}_{\mathrm{BHT}}$ & $7.83^{\mathrm{aA}} \pm 0.26$ & $7.45^{\mathrm{aB}} \pm 0.45$ & $7.29^{\mathrm{aB}} \pm 0.39$ & $6.37^{\mathrm{cdC}} \pm 0.67$ & $5.45^{\mathrm{bD}} \pm 0.39$ \\
\hline $\mathrm{C}_{\text {LFPE }}$ & $7.75^{\mathrm{aA}} \pm 0.39$ & $7.54^{\mathrm{aAB}} \pm 0.39$ & $7.33^{a B} \pm 0.38$ & $7.00^{\mathrm{abC}} \pm 0.36$ & $6.16^{\mathrm{aD}} \pm 0.44$ \\
\hline $\mathrm{K}_{\mathrm{C}}$ & $7.87^{\mathrm{aA}} \pm 0.22$ & $7.5^{\mathrm{aB}} \pm 0.42$ & $7.20^{\mathrm{aB}} \pm 0.39$ & $6.12^{\mathrm{dC}_{ \pm}} \pm 0.60$ & $5.04^{\mathrm{cD}_{ \pm}} \pm 0.49$ \\
\hline $\mathrm{K}_{\mathrm{BHT}}$ & $7.87^{\mathrm{aA}} \pm 0.31$ & $7.54^{\mathrm{aAB}} \pm 0.39$ & $7.37^{a B} \pm 0.37$ & $6.58^{\mathrm{bcC}_{ \pm}} \pm 0.55$ & $5.50^{\mathrm{bD}} \pm 0.36$ \\
\hline $\mathrm{K}_{\text {IFPE }}$ & $7.83^{\mathrm{aA}} \pm 0.32$ & $7.62^{\mathrm{aAB}} \pm 0.37$ & $7.37^{\mathrm{aBC}} \pm 0.37$ & $7.12^{\mathrm{aC}_{ \pm}}+0.43$ & $6.25^{\mathrm{aD}} \pm 0.50$ \\
\hline
\end{tabular}

Means with different small letter superscripts in a column and capital letter superscript in a row differ significantly (P $\leq 0.05$ ).

$\mathrm{C}_{\mathrm{C}}$ - Cobb control meat patties, $\mathrm{C}_{\mathrm{BHT}}$ - Cobb chicken patties with 100 ppm BHT, $\mathrm{C}_{\mathrm{LFE}}$ - Cobb chicken patties with 15 ml lychee fruit peel extract $\mathrm{K}_{\mathrm{C}}-$ Kadaknath chicken control patties, $\mathrm{K}_{\mathrm{BHT}}-$ Kadaknath chicken patties with 100 ppm BHT, $\mathrm{K}_{\mathrm{LFPE}}-\mathrm{Kadaknath}$ chicken patties with 15 ml lychee fruit peel extract.

Table 4: Effect of type of meat and incorporation of lychee fruit peel extract on tenderness scores of chicken meat patties packaged in aerobic conditions and stored at $4 \pm 2^{\circ} \mathrm{C}(\mathrm{Mean} \pm \mathrm{SD})(\mathrm{n}=12)$

\begin{tabular}{|c|c|c|c|c|c|}
\hline Treat & $\mathbf{0}$ & 4 & 8 & 12 & 16 \\
\hline$\overline{\mathrm{C}_{\mathrm{C}}}$ & $7.83^{\mathrm{aA}} \pm 0.24$ & $7.54^{\mathrm{a} A B} \pm 0.54$ & $7.25^{\mathrm{aB}} \pm 0.54$ & $6.5^{\mathrm{bcC}} \pm 0.56$ & $5.12^{\mathrm{dD}_{ \pm}} .48$ \\
\hline $\mathrm{C}_{\text {BHT }}$ & $7.79^{\mathrm{aA}} \pm 0.33$ & $7.54^{\mathrm{a} A \mathrm{~B}_{ \pm}} \pm .54$ & $7.29^{\mathrm{aB}} \pm 0.45$ & $6.58^{\mathrm{abcC}_{ \pm}} \pm 0.55$ & $5.62^{\mathrm{bcD}} \pm 0.48$ \\
\hline $\mathrm{C}_{\text {LFPE }}$ & $7.87^{\mathrm{aA}} \pm 0.31$ & $7.70^{\mathrm{aA}} \pm 0.33$ & $7.58^{\mathrm{aA}} \pm 0.41$ & $7.00^{\mathrm{aB}} \pm 0.42$ & $6.12^{\mathrm{aC}_{ \pm}} \pm 0.31$ \\
\hline $\mathbf{K}_{\mathbf{C}}$ & $7.70^{\mathrm{aA}} \pm 0.25$ & $7.41^{\mathrm{a} A \mathrm{~B}_{ \pm}} \pm .55$ & $7.16^{\mathrm{a}^{\mathrm{B}}} \pm 0.49$ & $6.41^{\mathrm{cC}} \pm 0.55$ & $5.04^{\mathrm{dD}_{ \pm}}+39$ \\
\hline $\mathbf{K}_{\mathrm{BHT}}$ & $7.75^{\mathrm{aA}} \pm 0.26$ & $7.41^{\mathrm{aAB}} \pm 0.55$ & $7.20^{\mathrm{aB}} \pm 0.49$ & $6.41^{\mathrm{cC}} \pm 0.55$ & $5.54^{\mathrm{cD}} \pm 0.33$ \\
\hline $\mathbf{K}_{\text {LFPE }}$ & $7.79^{\mathrm{aA}} \pm 0.25$ & $7.45^{\mathrm{aAB}} \pm 0.49$ & $7.33^{\mathrm{aB}} \pm 0.38$ & $6.91_{\mathrm{abc}} \pm 0.46$ & $5.91^{\mathrm{abD}} \pm 0.41$ \\
\hline
\end{tabular}

Means with different small letter superscripts in a column and capital letter superscript in a row differ significantly (P $\leq 0.05$ ).

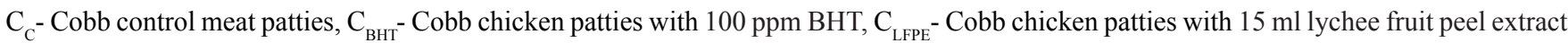
$\mathrm{K}_{\mathrm{C}}$ - Kadaknath chicken control patties, $\mathrm{K}_{\mathrm{BHT}}$ - Kadaknath chicken patties with 100 ppm BHT, $\mathrm{K}_{\text {LFPE }}$ Kadaknath chicken patties with 15 ml lychee fruit peel extract. 
Table 5: Effect of type of meat and incorporation of lychee fruit peel extract on juiciness scores of chicken meat patties packaged in aerobic conditions and stored at $4 \pm 2^{\circ} \mathrm{C}(\mathrm{Mean} \pm \mathrm{SD})(\mathrm{n}=12)$

\begin{tabular}{|c|c|c|c|c|c|}
\hline Treatn & 0 & 4 & 8 & 12 & 16 \\
\hline $\mathrm{C}_{\mathrm{C}}$ & $7.79^{\mathrm{aA}} \pm 0.25$ & $7.66^{\mathrm{aA}} \pm 0.32$ & $7.00^{\mathrm{aB}} \pm 0.70$ & $6.37^{\mathrm{bC}} \pm 0.52$ & $5.08^{\mathrm{cD}} \pm 0.19$ \\
\hline $\mathrm{C}_{\mathrm{BHT}}$ & $7.83^{\mathrm{aA}} \pm 0.24$ & $7.70^{\mathrm{aA}} \pm 0.33$ & $7.04^{\mathrm{aB}} \pm 0.65$ & $6.58^{\mathrm{bC}} \pm 0.46$ & $5.58^{\mathrm{bD}} \pm 0.46$ \\
\hline $\mathrm{C}_{\mathrm{LFPE}}^{\mathrm{BHI}}$ & $7.83^{\mathrm{aA}} \pm 0.24$ & $7.75^{\mathrm{aA}} \pm 0.26$ & $7.41^{\mathrm{aB}} \pm 0.51$ & $7.00^{\mathrm{aC}} \pm 0.42$ & $6.20^{\mathrm{aD}_{ \pm}} .49$ \\
\hline $\mathrm{K}_{\mathrm{C}}$ & $7.91^{\mathrm{aA}} \pm 0.19$ & $7.70^{\mathrm{aA}} \pm 0.33$ & $7.20^{\mathrm{aB}} \pm 0.45$ & $6.45^{\mathrm{bC}} \pm 0.54$ & $5.16^{\mathrm{cD}} \pm 0.32$ \\
\hline $\mathrm{K}_{\mathrm{BHT}}$ & $7.87^{\mathrm{aA}} \pm 0.22$ & $7.75^{\mathrm{aA}_{ \pm}} \pm 0.36$ & $7.25^{\mathrm{aB}_{ \pm}} \pm .39$ & $6.54^{\mathrm{bC}} \pm 0.49$ & $5.66^{\mathrm{bD}} \pm 0.49$ \\
\hline $\mathrm{K}_{\text {LFPE }}^{\text {BHI }}$ & $7.91^{\mathrm{aA}_{ \pm}} \pm .19$ & $7.79^{\mathrm{aA}} \pm 0.25$ & $7.45^{\mathrm{aB}} \pm 0.39$ & $7.08^{\mathrm{aC}} \pm 0.19$ & $6.29^{\mathrm{aD}} \pm 0.45$ \\
\hline
\end{tabular}

Means with different small letter superscripts in a column and capital letter superscript in a row differ significantly $(\mathrm{P} \leq 0.05)$.

$\mathrm{C}_{\mathrm{C}}$ - Cobb control meat patties, $\mathrm{C}_{\mathrm{BHT}}{ }^{-}$Cobb chicken patties with $100 \mathrm{ppm} \mathrm{BHT,} \mathrm{C}_{\mathrm{LFPE}}$ - Cobb chicken patties with $15 \mathrm{ml}$ lychee fruit peel extract $\mathrm{K}_{\mathrm{C}}$ - Kadaknath chicken control patties, $\mathrm{K}_{\mathrm{BHT}}$ - Kadaknath chicken patties with 100 ppm BHT, $\mathrm{K}_{\mathrm{LFPE}}-$ Kadaknath chicken patties with $15 \mathrm{ml}$ lychee fruit peel extract.

Table 6: Effect of type of meat and incorporation of lychee fruit peel extract on overall acceptability scores of chicken meat patties packaged in aerobic conditions and stored at $4 \pm 2^{\circ} \mathrm{C}(\mathrm{Mean} \pm \mathrm{SD})(\mathrm{n}=12)$

\begin{tabular}{|c|c|c|c|c|c|}
\hline Treat & 0 & 4 & 8 & 12 & 16 \\
\hline$\overline{\mathrm{C}_{\mathrm{C}}}$ & $7.87^{\mathrm{aA}} \pm 0.22$ & $7.58^{\mathrm{aA}} \pm 0.28$ & $7.12^{\mathrm{bB}} \pm 0.31$ & $6.04^{\mathrm{bC}} \pm 0.54$ & $4.95^{\mathrm{cD}} \pm 0.54$ \\
\hline $\mathrm{C}_{\mathrm{BHT}}$ & $7.87^{\mathrm{aA}} \pm 0.31$ & $7.62^{\mathrm{aA}} \pm 0.22$ & $7.25^{\mathrm{bB}} \pm 0.33$ & $6.41^{\mathrm{bC}} \pm 0.55$ & $5.58^{\mathrm{bD}} \pm 0.55$ \\
\hline $\mathrm{C}_{\mathrm{LFPE}}$ & $7.87^{\mathrm{aA}} \pm 0.22$ & $7.66^{\mathrm{aA}} \pm 0.32$ & $7.62^{\mathrm{aA}} \pm 0.22$ & $6.87^{\mathrm{aB}} \pm 0.50$ & $6.25^{\mathrm{aC}} \pm 0.50$ \\
\hline $\mathrm{K}_{\mathrm{C}}^{\text {LFE }}$ & $7.95^{\mathrm{aA}} \pm 0.14$ & $7.66^{\mathrm{aB}} \pm 0.24$ & $7.20^{\mathrm{bC}} \pm 0.25$ & $6.12^{\mathrm{bD}} \pm 0.39$ & $5.04^{\mathrm{cE}} \pm 0.39$ \\
\hline $\mathrm{K}_{\mathrm{BHT}}$ & $7.91^{\mathrm{aA}} \pm 0.19$ & $7.70^{\mathrm{aA}} \pm 0.25$ & $7.29^{\mathrm{bB}} \pm 0.25$ & $6.45^{\mathrm{bC}} \pm 0.51$ & $5.58^{\mathrm{bD}} \pm 0.51$ \\
\hline $\mathrm{K}_{\mathrm{IFPF}}^{\mathrm{DH1}}$ & $7.87^{\mathrm{aA}} \pm 0.22$ & $7.75^{\mathrm{aAB}_{ \pm}} \pm .26$ & $7.62^{\mathrm{aB}} \pm 0.22$ & $6.95^{\mathrm{aC}_{ \pm}} 0.39$ & $6.34^{\mathrm{aD}} \pm 0.39$ \\
\hline
\end{tabular}

Means with different small letter superscripts in a column and capital letter superscript in a row differ significantly $(\mathrm{P} \leq 0.05)$.

$\mathrm{C}_{\mathrm{C}}$ - Cobb control meat patties, $\mathrm{C}_{\mathrm{BHT}}$ - Cobb chicken patties with 100 ppm BHT, $\mathrm{C}_{\mathrm{LFPE}}$ - Cobb chicken patties with 15 ml lychee fruit peel extract $\mathrm{K}_{\mathrm{C}}$ - Kadaknath chicken control patties, $\mathrm{K}_{\mathrm{BHT}}-$ Kadaknath chicken patties with 100 ppm BHT, $\mathrm{K}_{\mathrm{LFPE}}-$ Kadaknath chicken patties with $15 \mathrm{ml}$ lychee fruit peel extract.

patties. On the $8^{\text {th }}$ day of refrigerated storage, LFPE treated both types of patties had significantly higher scores in comparison to both types of control patties.

On the $12^{\text {th }}$ day, extract treated kadaknath and cobb patties had significantly higher OAA scores in comparison to control patties with extract treated patties having better scores in comparison to BHT patties also. Verma et al. (2020) reported higher overall acceptability of goat meat nuggets incorporated with LP. Das et al. (2016) also reported the comparable OAA of the meat nuggets with LFPE with that of BHT and control on a fresh basis.

\section{pH}

$\mathrm{pH}$ has a direct bearing on the meat quality attributes such as tenderness, water-holding capacity, color, juiciness, and shelf-life (Table 7). The $\mathrm{pH}$ values ranged from 6.23 to 6.30 for cobb chicken fresh patties. The $\mathrm{pH}$ values ranged from 6.22 to 6.29 for kadaknath fresh patties. The addition of BHT, lychee aqueous extracts did not result in any significant effect on the $\mathrm{pH}$ of fresh and refrigerated stored kadaknath and cobb chicken meat patties.

There was a slight decrease in the $\mathrm{pH}$ of chicken meat patties on the $4^{\text {th }}$ day of refrigerated storage in all the treatments. Subsequently, $\mathrm{pH}$ increased on the $12^{\text {th }}$ and $16^{\text {th }}$ day of storage. This pattern in $\mathrm{pH}$ might be due to the combine action of psychrotrophic bacteria which ferment carbohydrate present in the ingredients used in the formulation of the product. The subsequent increment in the $\mathrm{pH}$ value was due to the liberation of metabolites 
Table 7: Effect of type of meat and incorporation of lychee fruit peel extract on $\mathrm{pH}$ value of chicken meat patties packaged in aerobic conditions and stored at $4 \pm 2^{\circ} \mathrm{C}($ Mean $\pm \mathrm{SD})(\mathrm{n}=6)$

\begin{tabular}{|c|c|c|c|c|c|}
\hline$\underbrace{\text { Storage days }}_{\text {Treatments }}$ & $\mathbf{0}$ & 4 & 8 & 12 & 16 \\
\hline$\overline{\mathrm{C}_{\mathrm{C}}}$ & $6.30^{\mathrm{aBC}_{ \pm}} \pm 0.09$ & $6.20^{\mathrm{aC}_{ \pm} 0.12}$ & $6.25^{\mathrm{aBC}_{ \pm} 0.04}$ & $6.34^{\mathrm{aAB}} \pm 0.08$ & $6.43^{\mathrm{aA}} \pm 0.08$ \\
\hline $\mathrm{C}_{\mathrm{BHT}}$ & $6.26^{\mathrm{aBC}_{ \pm 0} .06}$ & $6.15^{\mathrm{aC}_{ \pm 0} .08}$ & $6.24^{\mathrm{aBC}_{ \pm 0} .06}$ & $6.30^{\mathrm{aB}} \pm 0.10$ & $6.42^{\mathrm{aA}} \pm 0.12$ \\
\hline $\mathrm{C}_{\text {LFPE }}$ & $6.23^{\mathrm{aBC}_{ \pm 0}}$ & $6.14^{\mathrm{aC}_{ \pm}} 0.08$ & $6.23^{\mathrm{aBC}_{ \pm} 0.06}$ & $6.27^{\mathrm{aAB}_{ \pm}} 0.08$ & $6.38^{\mathrm{aA}} \pm 0.11$ \\
\hline $\mathrm{K}_{\mathrm{C}}^{\mathrm{LrT}}$ & $6.29^{\mathrm{aB}} \pm 0.13$ & $6.21^{\mathrm{aB}_{ \pm} 0.12}$ & $6.25^{\mathrm{aB}} \pm 0.04$ & $6.35^{\mathrm{aAB}} \pm 0.07$ & $6.44^{\mathrm{aA}} \pm 0.14$ \\
\hline $\mathrm{K}_{\mathrm{BHT}}^{\mathrm{c}}$ & $6.24^{\mathrm{aBC}_{ \pm} 0.06}$ & $6.17^{\mathrm{aC}_{ \pm} 0.07}$ & $6.23^{\mathrm{aBC}_{ \pm} 0.06}$ & $6.30^{\mathrm{aB}} \pm 0.10$ & $6.41^{\mathrm{aA}} \pm 0.12$ \\
\hline$K_{\text {IFPE }}$ & $6.22^{\mathrm{aB}} \pm 0.13$ & $6.15^{\mathrm{aB}_{ \pm} 0.07}$ & $6.24^{\mathrm{aB}} \pm 0.06$ & $6.27^{\mathrm{aAB}} \pm 0.08$ & $6.38^{\mathrm{aA}} \pm 0.11$ \\
\hline
\end{tabular}

Means with different small letter superscripts in a column and capital letter superscript in a row differ significantly ( $\mathrm{P} \leq 0.05)$.

$\mathrm{C}_{\mathrm{C}}$ - Cobb control meat patties, $\mathrm{C}_{\mathrm{BHT}}-$ Cobb chicken patties with 100 ppm BHT, $\mathrm{C}_{\mathrm{LFPE}}$ - Cobb chicken patties with 15 ml lychee fruit peel extract $\mathrm{K}_{\mathrm{C}^{-}}$Kadaknath chicken control patties, $\mathrm{K}_{\mathrm{BHT}}{ }^{-}$Kadaknath chicken patties with 100 ppm BHT, $\mathrm{K}_{\mathrm{LFPE}}-$ Kadaknath chicken patties with $15 \mathrm{ml}$ lychee fruit peel extract.

Table 8: Effect of type of meat and incorporation of lychee fruit peel extract on TBA value (mg malonaldehyde/kg) of chicken meat patties packaged in aerobic conditions and stored at $4 \pm 2^{\circ} \mathrm{C}(\mathrm{Mean} \pm \mathrm{SD})(\mathrm{n}=6)$

\begin{tabular}{|c|c|c|c|c|c|}
\hline Treatments & 0 & 4 & 8 & 12 & 16 \\
\hline $\mathrm{C}_{\mathrm{C}}$ & $0.56^{\mathrm{aD}_{ \pm} 0.07}$ & $0.64^{\mathrm{aD}} \pm 0.27$ & $1.06^{\mathrm{aC}} \pm 0.04$ & $1.63^{\mathrm{aB}} \pm 0.24$ & $1.94^{\mathrm{aA}} \pm 0.14$ \\
\hline $\mathrm{C}_{\mathrm{BHT}}$ & $0.54^{\mathrm{abC}} \pm 0.10$ & $0.62^{\mathrm{aC}_{ \pm}} \pm 0.20$ & $0.88^{a b B_{ \pm}} \pm 0.04$ & $1.21^{\mathrm{bA}} \pm 0.22$ & $1.41^{\mathrm{bA}} \pm 0.30$ \\
\hline $\mathrm{C}_{\mathrm{LFPE}}^{\mathrm{BHT}}$ & $0.44^{\mathrm{bB}} \pm 0.07$ & $0.54^{\mathrm{aB}} \pm 0.08$ & $0.78^{\mathrm{bA}} \pm 0.31$ & $0.85^{\mathrm{CA}^{\mathrm{A}} \pm 0.08}$ & $0.85^{\mathrm{cA}} \pm 0.09$ \\
\hline $\mathrm{K}_{\mathrm{C}}^{\mathrm{LPE}}$ & $0.56^{\mathrm{aD}_{ \pm}} 0.08$ & $0.62^{\mathrm{aD}} \pm 0.26$ & $1.04^{\mathrm{aC}} \pm 0.05$ & $1.62^{\mathrm{aB}} \pm 0.24$ & $1.92^{\mathrm{aA}} \pm 0.16$ \\
\hline $\mathrm{K}_{\mathrm{BHT}}$ & $0.52^{\mathrm{abC}} \pm 0.11$ & $0.60^{\mathrm{aC}_{ \pm}} \pm 0.20$ & $0.88^{\mathrm{abB}_{ \pm}} \pm 0.4$ & $1.19^{\mathrm{bA}} \pm 0.25$ & $1.38^{\mathrm{bA}} \pm 0.32$ \\
\hline $\mathrm{K}_{\mathrm{IFPE}}^{\mathrm{BHI}}$ & $0.44^{\mathrm{bB}} \pm 0.07$ & $0.56^{\mathrm{aB}} \pm 0.08$ & $0.79^{\mathrm{bA}} \pm 0.31$ & $0.86^{\mathrm{cA}} \pm 0.99$ & $0.87^{\mathrm{CA}} \pm 0.08$ \\
\hline
\end{tabular}

Means with different small letter superscripts in a column and capital letter superscript in a row differ significantly $(\mathrm{P} \leq 0.05)$.

$\mathrm{C}_{\mathrm{C}}$ - Cobb control meat patties, $\mathrm{C}_{\mathrm{BHT}}$ - Cobb chicken patties with 100 ppm BHT, $\mathrm{C}_{\mathrm{LFPE}}$ - Cobb chicken patties with 15 ml lychee fruit peel extract $\mathrm{K}_{\mathrm{C}}$ - Kadaknath chicken control patties, $\mathrm{K}_{\mathrm{BHT}}-$ Kadaknath chicken patties with 100 ppm BHT, $\mathrm{K}_{\mathrm{LFPE}}$ - Kadaknath chicken patties with $15 \mathrm{ml}$ lychee fruit peel extract.

from the bacterial activities as the microbial load enhance with the storage period. At the end of the storage period of 16 days, the $\mathrm{pH}$ of each patty was significantly higher in comparison to its fresh counterpart. The $\mathrm{pH}$ of all samples varied from 6.38 to 6.44 at the end of the refrigerated storage period of 16 days. Sasse et al. (2009) reported that $\mathrm{pH}$ increased significantly in BHT, BHA, grape seed extract and oregano extract treated cooked pork patties during frozen storage

Devi et al. (2018) in guinea fowl sausage and Dharmaveer et al. (2007) in restructured chicken chunk also observed an increasing pattern in $\mathrm{pH}$ under vacuum packaged at refrigeration temperature. The lower $\mathrm{pH}$ of sheep nuggets with LFPE as compared to control was also reported by Das et al. (2016). The results were comparable to the studies conducted by Verma et al. (2020) with incorporation lychee pericarp and Lychee seed extract incorporation as suggested by Kumar (2014).

\section{Thiobarbituric acid (TBA) value}

The TBA value of both kadaknath and cobb fresh patties ranged from 0.44 to $0.56 \mathrm{mg}$ malonaldehyde $/ \mathrm{kg}$ (Table 8 ). LFPE treated patties had significantly lower TBA values in comparison to control and BHT treated patties on 0 day. TBA values increased significantly in all the treatments during storage. On the $8^{\text {th }}$ day of storage, both kadaknath and cobb extract treated patties had significantly lower TBA values in comparison to control and this trend was maintained up to the end of the storage period. From $12^{\text {th }}$ day onwards, extract treated patties had significantly lower TBA values in comparison to BHT. From the $12^{\text {th }}$ 
day of storage, BHT patties also had significantly lower TBA values in comparison to control patties up to the end of the storage. On the $16^{\text {th }}$ day, both kinds of LFPE patties had lower TBA value than control and BHT. But overall TBA value of all the samples increased from the 0 day till 16 days. This could be due to increased lipid oxidation and the production of volatile metabolites in the presence of oxygen during storage.

A similar trend in TBA value was noticed in vacuum packaged meat patties and ready to eat Vawksa rep by Jimenez et al. (2007), Kala et al. (2007). It was observed that BHT, LFPE extracts had better protection against a rise in TBA values in comparison to control patties during refrigerated storage. It was also observed that LFPE extract resulted in more inhibition in TBA values in comparison to BHT during refrigerated storage. Kumar et al. (2014) also reported that during storage, the LSE treated samples showed significant fewer TBARS as compared to the control samples because the phenolic compounds might be involved in the inhibition of lipid oxidation, by inhibiting free radical formation, by preventing the propagation of free radical chain reactions through the chelation of transition metal ions. Ahmad et al. (2015), Jongberg et al. (2011) in their studies have also reported that the incorporation of plant extracts containing phenolic and flavonoid compounds retarded lipid oxidation in meat products during storage.

\section{Microbiological evaluation}

\section{Total plate count (TPC)}

The TPC values were statistically similar among control and treatments on day 0 of storage and varied from $2.38 \mathrm{log}$ $\mathrm{cfu} / \mathrm{g}$ to $2.52 \mathrm{log} \mathrm{cfu} / \mathrm{g}$ in cobb patties (Table 9). On 0 day in kadaknath patties the count ranged from $2.36 \mathrm{log} \mathrm{cfu} / \mathrm{g}$ to $2.49 \log \mathrm{cfu} / \mathrm{g}$. The TPC significantly increased with the progression of storage, irrespective of the treatment types. From $8^{\text {th }}$ day onwards, LFPE patties had significantly lower TPC in comparison to controls. On the $16^{\text {th }}$ day, treatments LFPE had lower TPC in comparison to control. LFPE treated patties had the lowest TPC of $4.60 \mathrm{log} \mathrm{cfu} / \mathrm{g}$ and the control had the highest TPC of $5.92 \mathrm{log} \mathrm{cfu} / \mathrm{g}$ on the $16^{\text {th }}$ day of refrigerated storage. On the 16 th day both BHT treated patties had TPC of $5.28 \mathrm{log} \mathrm{cfu} / \mathrm{g}$. Results indicate that Lychee peel extract possesses antimicrobial activity. Polyphenols play an important role in protein precipitation and enzyme inhibition of microorganisms. The mechanism responsible for phenolic toxicity to microorganisms is related to reaction with sulphydryl groups of proteins and the unavailability of substrates to microorganisms (Machado et al. 2003; Naz et al. 2007).

Singh et al. (2013) reported that by comparing the inhibitory action of all three kinds of lychee peel extract i.e acetone water and ethanol extract, it was found that the acetone extract has the most prominent effect on all

Table 9: Effect of type of meat and incorporation of lychee fruit peel extract on Total plate count (log cfu/g) of chicken meat patties packaged in aerobic conditions and stored at $4 \pm 2^{\circ} \mathrm{C}($ Mean $\pm \mathrm{SD})(\mathrm{n}=6)$

\begin{tabular}{|c|c|c|c|c|c|}
\hline Treat & $\mathbf{0}$ & 4 & 8 & 12 & 16 \\
\hline $\mathrm{C}_{\mathrm{C}}$ & $2.44^{\mathrm{aE}_{ \pm}} .49$ & $3.46^{\mathrm{aD}_{ \pm} 0.56}$ & $4.11^{\mathrm{aC}_{ \pm}}+34$ & $5.07^{\mathrm{aB}} \pm 0.38$ & $5.92^{\mathrm{aA}} \pm 0.55$ \\
\hline $\mathrm{C}_{\mathrm{BHT}}$ & $2.52^{\mathrm{aD}_{ \pm 0}} \pm .19$ & $3.46^{\mathrm{aC}_{ \pm}} \pm 0.53$ & $3.80^{\mathrm{abC}} \pm 0.47$ & $4.60^{\mathrm{abB}_{ \pm}} \pm 0.59$ & $5.28^{\mathrm{abA}} \pm 0.60$ \\
\hline $\mathrm{C}_{\mathrm{LFPE}}$ & $2.38^{\mathrm{aA}} \pm 0.59$ & $2.96^{\mathrm{a}} \pm 0.41$ & $3.42^{\mathrm{bBC}_{ \pm}} \pm 0.42$ & $3.94^{\mathrm{bB}} \pm 0.58$ & $4.61^{\mathrm{bA}} \pm 0.36$ \\
\hline $\mathrm{K}_{\mathrm{C}}$ & $2.41^{\mathrm{aE}_{ \pm 0}} .58$ & $3.38^{\mathrm{aD}_{ \pm}} \pm 0.69$ & $4.09^{\mathrm{aC}} \pm 0.42$ & $5.05^{\mathrm{aB}} \pm 0.53$ & $5.89^{\mathrm{aA}_{ \pm}} \pm .63$ \\
\hline $\mathrm{K}_{\mathrm{BHT}}$ & $2.49^{\mathrm{aD}_{ \pm 0}} .26$ & $3.43^{\mathrm{aC}_{ \pm}} \pm 0.59$ & $3.78^{\mathrm{abC}_{ \pm}} \pm 0.54$ & $4.58^{\mathrm{abB}_{ \pm 0}} .68$ & $5.28^{\mathrm{abA}} \pm 0.66$ \\
\hline $\mathrm{K}_{\mathrm{LFPE}}$ & $2.36^{\mathrm{aD}_{ \pm}} 0.66$ & $2.93^{\mathrm{aCD}_{ \pm 0}} .37$ & $3.37^{\mathrm{bBC}_{ \pm}} \pm .46$ & $3.93^{\mathrm{bB}} \pm 0.66$ & $4.60^{\mathrm{bA} \pm 0.40}$ \\
\hline
\end{tabular}

Means with different small letter superscripts in a column and capital letter superscript in a row differ significantly ( $\mathrm{P} \leq 0.05)$.

$\mathrm{C}_{\mathrm{C}}$ - Cobb control meat patties, $\mathrm{C}_{\mathrm{BHT}}$ - Cobb chicken patties with 100 ppm BHT, $\mathrm{C}_{\mathrm{LFE}}$ - Cobb chicken patties with $15 \mathrm{ml}$ lychee fruit peel extract $\mathrm{K}_{\mathrm{C}}$ - Kadaknath chicken control patties, $\mathrm{K}_{\mathrm{BHT}}$ - Kadaknath chicken patties with 100 ppm BHT, $\mathrm{K}_{\mathrm{LPPE}}-\mathrm{Kadaknath}$ chicken patties with 15 ml lychee fruit peel extract. 
Table 10: Effect of type of meat and incorporation of lychee fruit peel extract on Psychrotrophic count (log cfu/g) of chicken meat patties packaged in aerobic conditions and stored at $4 \pm 2^{\circ} \mathrm{C}($ Mean $\pm \mathrm{SD})(\mathrm{n}=6)$

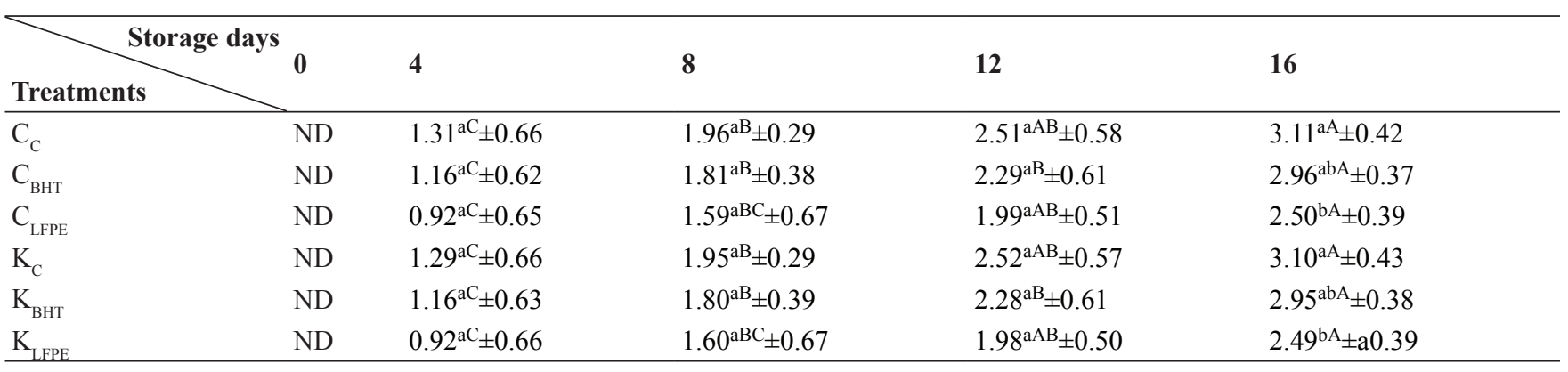

Means with different small letter superscripts in a column and capital letter superscript in a row differ significantly $(\mathrm{P} \leq 0.05)$.

$\mathrm{C}_{\mathrm{C}}$ - Cobb control meat patties, $\mathrm{C}_{\mathrm{BHT}}$ - Cobb chicken patties with $100 \mathrm{ppm} \mathrm{BHT,} \mathrm{C}_{\mathrm{LFPE}}$ - Cobb chicken patties with 15 ml lychee fruit peel extract $\mathrm{K}_{\mathrm{C}}$ - Kadaknath chicken control patties, $\mathrm{K}_{\mathrm{BHT}}-$ Kadaknath chicken patties with 100 ppm BHT, $\mathrm{K}_{\mathrm{LFPE}}-$ Kadaknath chicken patties with $15 \mathrm{ml}$ lychee fruit peel extract.

bacterial species, followed by the ethanol extract. On the other hand, the moderate effect of water extract was observed on all gram-negative as well as gram-positive bacteria species.

\section{Psychrotrophic count}

On 0 day there were no psychrotrophic that could be due to the death of psychrotrophic because of heat treatment (Table 10). On $4^{\text {th }}$ day Psychrotrophic count of control and treated cobb patties ranged from $0.92 \log \mathrm{cfu} / \mathrm{g}$ to $1.31 \mathrm{log}$ $\mathrm{cfu} / \mathrm{g}$.

On $4^{\text {th }}$ day Psychrotrophic count of control and treated kadaknath patties ranged from $0.92 \log \mathrm{cfu} / \mathrm{g}$ to $1.29 \mathrm{log}$ $\mathrm{cfu} / \mathrm{g}$. An increase in storage period led to a significant increase in psychrotrophic counts in all the treatments. At the end of refrigerated storage, Psychrotrophic count in cobb patties varied from 2.50 to $3.11 \mathrm{log} \mathrm{cfu} / \mathrm{g}$ and in kadaknath patties the count was $2.49 \log \mathrm{cfu} / \mathrm{g}$ to 3.10 $\log \mathrm{cfu} / \mathrm{g}$. LFPE treated patties had a significantly lower psychrotrophic count in comparison to control at the end of storage. Findings were in correlation with the study conducted by Sharma et al. (2019) in pomegranate powder aqueous extract incorporation in meat patties. Badole et al. (2019) reported that no Psychrotrophic were found on 0 day of storage periods of low fat kadaknath meat patties.

\section{CONCLUSION}

The study concluded that incorporation of $15 \mathrm{ml}$ lychee peel aqueous extract per $100 \mathrm{~g}$ of kadaknath and cobb chicken meat individually resulted in the production of healthier patties. Lychee peel extract-treated patties had significantly better sensory scores and were moderately acceptable at the end of storage of 16 days whereas control patties were slightly acceptable at the end of refrigerated storage. Lychee extract provided better protection against oxidative rancidity and microbial spoilage during refrigerated storage and can be used as a deserving substitute for synthetic antioxidants like BHT.

\section{ACKNOWLEDGEMENTS}

The authors are thankful to Head of Department, Department of Livestock Products Technology, College of Veterinary Sciences, Lala Lajpat Rai University of Veterinary \& Animal Sciences, Hisar for providing necessary facilities.

\section{REFERENCES}

Ahmad, S., Gokulakrishnan, P., Giriprasad, R. Yatoo, M. 2015. Fruit based natural antioxidants in meat and meat products: A review. Crit. Rev. Food Sci. Nutr., 55: 1503-1513.

Aun, M.V., Mafra, C., Philippi, J.C., Kalil, J., Agondi, R.C. Motta, A.A. 2011. Aditivos em alimentos. Revista Brasileira de Alergiae. Imunopatologia, 34: 167-174.

Azad, M.2018. Introduction of unique black chicken meat variety (Kadaknath) in hilly areas Jammu and Kashmir, India. J. Plant Physiol. Pathol., 6: 53-54. 
Badole, S., Nayak, N.K., Mehta, M.K. and Aich, R. 2019. Storage Stability of Functional Kadaknath Chicken Patties under Vacuum Packaging. Int. J. Curr. Microbiol. App. Sci., 8(11): 2585-2593.

BAHFS. 2019. Basic Animal Husbandry and Fisheries Statistics.Government of India, Ministry of Fisheries, Animal Husbandry and Dairying.Department of Animal Husbandry and Dairying. Krishi Bhawan, New Delhi.

Bhat, Z.F., Pathak, V. Bukhari, S. A. A., Anmad, S. R. and Bhat, H. 2011. Quality changes in chevon herrisa (meat based product) during refrigerated storage. Int. J. Meat Sci.,1(1): $52-61$

Chand, R., Pal, P., Singh, A. 2011. Farm size and productivity: understanding the strengths of smallholders and their livelihoods. Econ. Polit. Wkly ., 54: 5-11.

Das, A. K., Rajkumar, V., Nanda, P. K., Chauhan, P., Pradhan, S.R., Biswas, S. 2016. Antioxidant Efficacy of Lychee (Lychee chinensis Sonn.) Pericarp Extract in Sheep meat nuggets, Antioxidants., 5(2): 16.

Devatkal, S., Mendiratta, S. K., and Anjaneyulu, A. S. R. 2003. Effect of calcium lactate on the quality and shelf life of restructured pork rolls. J. Meat Sci., 1: 1-6.

Devi, R. Singh, P. 2018. Studies on Proximate Composition of Vacuum Packed Guinea Fowl Meat Sausages during Storage

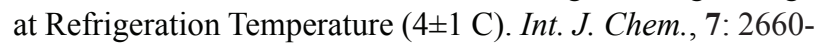
2666.

Dharmaveer, S., Rajkumar, V. and Mukesh, K. P. 2007. Am. J. Food Technol., 2: 238-247.

FSSAI. 2011. Recommended methods for microbiological examination of foods, India.

Jimenez, F. 2007. Novel applications of oil-structuring methods as a strategy to improve the fat content of meat products. Trends Food Sci. Technol., 18: 567-578.

Jongberg, S., Skov, S.H., Torngren, M.A., Skibsted, L.H. Lund, M.N. 2011. Effect of white grape extract and modified atmosphere packaging on lipid and protein oxidation in chill stored beef patties. Food Chem., 128: 276-283

Kala, R.K., Kondaiah, N., Anjaneyulu, A.S.R. and Thomas, R. 2007. Evaluation of quality of chicken emulsions stored refrigerated $\left(4 \pm 1{ }^{\circ} \mathrm{C}\right)$ for chicken patties. Int. J. Food Sci. Technol., 42(7): 842-851.

Kandeepan, G., Anjaneyullu, A.S.R., Kondaiah, N. and Mendiratta, S.K. 2010. Quality of buffalo meat keema at different storage temperature. Afr. J. Food Sci., 4(6): 410417.

Keeton, J.T. 1983. Effect of fat, $\mathrm{NaCl}$ and phosphate levels on the chemical and sensory properties of pork patties. J. Food Sci., 48: 878-81.

Kumar, Y., Yadav, D., Ahmad, T. and Narsaiah, K. 2014.
Antioxidant Effect of Litchi (Litchi chinensis Sonn.) Seed Extract on Raw Ground Chicken Meat Stored at $4 \pm 1{ }^{\circ} \mathrm{C}$. Int. J. Food Process. Technol., 1: 20-25.

Kumar, Y., Yadav, D., Ahmad, T. and Narsaiah, K. 2015. Recent Trends in the Use of Natural Antioxidants for Meat and Meat Products. Compr. Rev. Food Sci. Food Chem., 14(6): 796812.

Li, W., Liang, H., Zhang, M.W., Zhang, R.F., Deng, Y.Y., Wei, Z.C., Zhang, Y. Tang, X.J. 2012. Phenolic profiles and antioxidant activity of Lychee (Lychee chinensis Sonn.) fruit pericarp from different commercially available cultivars. Molecules, 17: 14954-14967.

Lin, Y., Chang, J., Cheng, S., Wang, C., Jhan, Y., Lo, I., Hsu, Y., Liaw, C., Hwang, C. Chou, C. 2015. New bioactive chromanes from Litchi chinensis. J. Agric. Food Chem., 63: 2472-2478.

Machado, T., Pinto, A., Pinto, M., Leal, I., Silva, M., Amaral, A., Kuster, R. Netto, dosSantos. K. 2003. In vitro activity of Brazilian medicinal plants, naturally occurring naphthoquinones and their analogues, against methicillinresistant Staphylococcus aureus. Int. J. Antimicrob. Agents, 21: 279-284.

Mir. N. A., Rafiq, A., Kumar, F., Singh, V. Shukla, V. 2017. Determinants of broiler chicken meat quality and factors affecting them: a review. J. Food Sci. Technol., 54(10): 2997-3009.

Nayak, N.K., Pathak, V., Singh, V.P., Goswami, M., Bharti, S.K. 2014. Quality of Carrageenan Incorporated Low Fat Chicken Nuggets during Refrigerated Storage at $4^{\circ} \mathrm{C}$. Int. J. Livest. Res., 3(1): 7-13.

Naz, S., Siddiqi, R., Ahmad. S., Rasool, S. Sayeed, S. 2007. Antibacterial activity directed isolation of compounds from Punica granatum. J. Food Sci., 7: 341-345.

Pareek, S., 2016. Nutritional and Biochemical Composition of Lychee (Litchi Chinensis Sonn.). Cultivars., pp. 395-418.

Pereira, L.F.S., Inácio, M.L.C., Pereira, R.C. and AngelisPereira, M.C. 2015. Prevalênciade Aditivosem Alimentos Industrializados Comercializadosemuma Cidadedo Sul de Minas Gerais. Revista Ciências em Saúde, 5.

Sasse, A., Colindres, P. and Brewer, M.S. 2009. Effect of natural and synthetic antioxidants on the oxidative stability of cooked, frozen pork patties. J. Food Sci., 74(1): S30-S35.

Sharma, P. 2019. Development of chicken meat patties by using pomegranate fruit waste. PG thesis, LUVAS, Hisar.

Singh, J.P., Singh, S.k., Chandel, R. and Mishra, B. 2013. Evaluation of Antimicrobial and Antioxidant Property of Lychee's Seed for Therapeutic Purpose. Int. J. Pharm. Sci. Rev., 19(2): 72-76. 
Sudheer, K., Das, C., Mandal, P.K., Pal, U.K. and Rao, V.K. 2011. Quality characteristics of restructured chicken cubes incorporating spent chicken meat. Int. J. Meat Sci., 1: 62-69.

Trout, E.S., Hunt, M.C., Johson, D.E., Clans, J.R., Castner, C.L. and Kroff, D.H. 1992. Characteristics of low fat ground beef containing texture modifying ingredients. J. Food Sci., 57: 19-24.

U.S. Department of Agriculture, Agricultural Research Service. 2012. USDA National Nutrient Database for Standard Reference, Release 25. Nutrient Data Laboratory.

Uikey, S., Nayak, N.K., Mehta, M.K., Chhabra, D. and Chauhan, L. 2018. Storage stability of high fibre: low fat kadaknath chicken nuggets under refrigeration. Int. J. Microbiol., 10(10): 1381-1385.
Verma, A.K., Rajkumar, V. and Kumar, S. 2020. Influence of lychee pericarp powder on quality and Lychee chinensis storage stability of goat meat nuggets. Indian J. Small Ruminants., 26(1): 104-111.

Verma, L.P., Sonkar, N., Verma, C. 2020. Kadaknath chicken farming: Empowering Indian rural economy: A review. $J$. Pharm. Innov., 9(3): 266-268.

Witte, V.C., Krouze, G.F. and Bailey, M.E. 1970. Anew extraction method for determining 2-thiobarbituric acid values of pork and beef during storage. J. Food Sci., 35: 582-585. 
